\title{
BINGKAI MEDIA PEMBERITAAN KEKERASAN SEKSUAL TERHADAP ANAK (STUDI KOMPARASI KOMPAS.COM DAN DETIK.COM)
}

\author{
Gufran 1, Rosmini ${ }^{2}$, Rahmawati latief ${ }^{3}$ \\ 1,2,3Universitas Islam Negeri Alauddin Makassar \\ Email: gufransmk2baus@gmail.com ${ }^{1}$, rosmini.amin@uin-alauddin.ac.id ${ }^{2}$, \\ rahma.latief@gmail.com ${ }^{3}$
}

\begin{abstract}
Abstrak:
Penelitian ini bertujuan untuk menganalisis teks berita pada media online Kompas.com dan Detik.com yang mengangkat isu kekerasan seksual terhadap anak periode terbit Juli 2020. Selain itu penelitian ini membandingkan bingkai berita di dua media untuk menunjukan kecenderungan media dalam pemberitaannya. Jenis penelitian ini adalah Penelitian deskriptif kualitatif menggunakan metode pengolahan data analisis framing, yaitu suatu pendekatan untuk mengetahui kenyataan yang ada yang dibangun serta dibentuk oleh media. Teknik analisis framing menggunakan model Entman. Model ini didasari pada penyeleksian dan penonjolan isu yaitu Problem Identification, Causal Interpretation, Moral Judgment, serta terakhir adalah Treatment Recommendation. Hasil penelitian ini menemukan bahwa Kompas.com melindungi korban dengan tidak memberikan ruang lebih untuk pelaku membela diri pada publik melalui media. Hal ini dapat dilihat pada konten beritanya memuat banyak komentar dari pihak kepolisian bahkan tidak mengutip satupun keterangan pelaku. Sementara Detik.com pada beberapa beritanya memuat komentar atau kutipan wawancara pelaku. Hal ini memberikan gambaran kepada pembaca bahwa Detik.com cenderung memberikan ruang kepada pelaku yang menceritakan kejadian berdasarkan sudut pandang pelaku.
\end{abstract}

Kata Kunci: Kekerasan, Seksual, Framing, Anak, Media, Komparasi

\begin{abstract}
This research was aimed to recognize media text of Kompas.com and Detik.com which focused on the sexual violence case of child on periode of July 2020. It also distinguished both media to present their tendency of that case. A qualitative descriptive method was the type of this research with analysis framing approach. The framing analysis used Robert Entman technique. It was considered by selection and issue highlight, namely Problem Identification, Causal Interpretation, Moral Judgment, and Treatment Recommendation. The result of this study figured out that Kompas.com protected the victim by not giving so much space for perpetrator to defence himself before publicin media. It could be found by seeing so many statement from polices while the perpetrator was not. However, Detik.com showed up so many speech from him. It explained that Detik.com provided more space to him in telling the case according to his points.
\end{abstract}

Key words: Comparation, Child, Framing, Media, Sexual violence 


\section{PENDAHULUAN}

Kekerasan terhadap perempuan dan anak tidak saja merupakan masalah individu, melainkan juga masalah nasional dan sudah menjadi masalah global (Hasanah, 2013). Hal ini mendorong lembaga internasional seperti UNICEF (United Nations Children's Fund) atau Dana Anak Perserikatan Bangsa-Bangsa, dan WHO (World Health Organization) atau organisasi kesehatan dunia dan lembaga internasional sejenisnya yang merupakan lembaga dunia untuk membantu anakanak di berbagai negara terhadap masalah yang dihadapi anak termasuk kekerasan.

Faktanya $88 \%$ atau hampir setiap negara di dunia memiliki undang-undang untuk melindungi anak dari kekerasan, tetapi kurang dari 47\% mengatakan mereka memiliki lembaga penegak hukum. Kekerasan terhadap anak terjadi ketika negara gagal menerapkan strategi dan kebijakan yang dirancang untuk melindungi anak. Bahkan data menunjukkan bahwa setengah dari total populasi anak dunia, atau sekitar satu miliar anak, mengalami kekerasan fisik, kekerasan seksual, kekerasan psikologis, luka dan cacat, dan meninggal. Menurut laporan tersebut, 40.150 anak berusia 0 hingga 17 tahun meninggal di seluruh dunia akibat kekerasan, dan laporan tersebut menambahkan bahwa 120 juta anak perempuan dan perempuan muda di bawah usia 20 tahun mengalami pelecehan seksual (www.republika.co.id)

Fenomena serupa juga terjadi di Indonesia. Kasus kekerasan seksual akhirakhir ini marak diperbincangkan. Korbannya bukan hanya pada orang dewasa atau remaja tapi juga bahkan merambah ke anak-anak dan juga balita Perlindungan Saksi dan Korban (LPSK) mencatat peningkatan jumlah permohonan perlindungan dari kekerasan seksual terhadap anak. Menurut LPSK, jumlah kekerasan seksual terhadap anak meningkat menjadi 25 sejak 2016, meningkat menjadi 81 pada 2017 dan memuncak pada 206 pada 2018, dan terus meningkat (www.detik.com). Sementara itu menurut data Lembaga Perlindungan Saksi dan Korban (LPSK), pada tahun 2019 menemukan sebanyak 350 perkara kekerasan seksual pada anak (Fitriani, dkk, 2021:35). Bahkan meningkat tajam saat memasuki tahun 2020 terhitung sejak Januari hingga Juli kasus kekerasan seksual terhadap anak mencapai 2.556 (www.kompas.com). 
Lebih tepatnya dapat dilihat pada tabel di bawah ini :

Tabel 1. Data kekerasan seksual terhadap anak Januari 2017-Juli 2020

\begin{tabular}{ccc}
\hline No & Tahun & Kasus \\
\hline 1 & 2017 & 81 \\
2 & 2018 & 206 \\
3 & 2019 & 350 \\
4 & 2020 & 2.556 \\
\hline
\end{tabular}

Sumber : Data Sekunder Peneliti, Februari 2021

Pelecehan seksual anak adalah pemaksaan, intimidasi, atau penipuan anak dalam aktivitas seksual. Aktivitas seksual tersebut meliputi visual, taktil, penyisipan (tekanan), pelecehan, dan pemerkosaan. (Paramasatri, dkk, 2010). Menurut seorang penulis dan sosiolog Amerika Ricard J. Gelles (Hurairah, 2012) menjelaskan bahwa kekerasan terhadap anak merupakan perbuatan yang disengaja sehingga menimbulkan kerugian atau bahaya terhadap anak-anak (baik secara fisik maupun psikis). Kekerasan secara fisik bukan hanya menimbulkan luka saja tapi di beberapa kasus dapat mengakibatkan kematian terhadap korban. Sedangkan akibat yang diterima oleh korban kekerasan seksual secara psikologis dapat menimbulkan trauma yang berkepanjangan terhadap hal-hal yang telah dialami oleh korban. Fenomena kasus kekerasan seksual yang dialami anak hingga detik ini masih menjadi masalah yang cukup besar di Indonesia.

Seks dalam berita merupakan nilai berita yang sangat penting. Sehingga dapat memberikan daya tarik atau nilai lebih dalam proses penulisan berita. Kegiatan sehari-hari yang dilakukan orang secara pribadi, seperti bekerja, belajar, dan berdoa, tidak ada yang istimewa. Namun peristiwa seperti pembunuhan, huru hara, demonstrasi, gempa bumi, dan konferensi internasional tentu merupakan peristiwa menarik yang harus diketahui banyak orang. Pemberitaan kekerasan seksual di media online juga tidak kalah banyak. Jika melakukan penelusuran data di mesin pencarian google tentang kasus kekerasan seksual terhadap anak, maka akan banyak sekali ditemukan beberapa media online memberitakan kasus ini. Bahkan di media sosial kasus ini menjadi trending topik. Portal berita online Kompas.com 
dan Detik.com menyajikan hal serupa agar dapat memenuhi kebutuhan masyarakat akan informasi intelektual. Alasan peneliti memilih situs berita online Detik.com dan Kompas.com adalah karena situs ini termasuk situs pemberitaan yang banyak diakses oleh pembaca (www.alexa.com).

Selain itu, Kompas.com dan Detik.com cukup sering mengulas dan membahas lebih detail pemberitaan kasus kekerasan seksual terhadap anak dibandingkan dengan media lainnya di sini peneliti mengambil 4 media online sebagai perbandingan yaitu tirto.id, liputan.com, okezone.com dan kumparan.com. Jika kita memasukkan kata kunci "WNA Perancis seksual anak" di mesin pencarian (google) maka yang muncul di halaman awal pencarian hasilnya tirto.id memuat 2 berita, liputan.com memuat 2 berita, okezone.com memuat 3 berita, dan kumparan 6 berita. Sedangkan untuk kompas.com memuat 14 berita dan Detik.com memuat 8 berita. Selain jumlah beritanya, peneliti juga melihat kedua media ini baik Kompas.com dan Detik.com mengemas judul berita isu kekerasan seksual terhadap anak ini berbeda. Cara tersebut digunakan demi menggaet minat pembaca serta dijadikan senjata utama sehingga meningkatkan sirkulasi (Setiati, 2005).

Alasan peneliti memilih periode penelitian hanya pada bulan Juli karena, pertama, berdasarkan laporan data Lembaga Perlindungan Saksi dan Korban (LPSK) terbaru menyebutkan bahwa data kekerasan seksual terhadap anak di masa pandemi meningkat dan memuncak sampai bulan Juli 2020. Kedua, setelah melakukan observasi pada Detik.com dan Kompas.com berita kekerasan seksual terhadap anak banyak dimuat pada bulan Juli yaitu sebanyak 91 berita. Hal ini pun turut membuat media online memberitakan kasus yang ada dengan semenarik mungkin untuk dapat dilirik pembaca.

Untuk menganalisis berita yang disajikan oleh dua media di atas. Peneliti akan menggunakan analisis framing model Robert N Entman, model ini dianggap lebih tepat digunakan oleh peneliti. Selain itu peneliti juga lebih paham mengenai model tersebut. Maka dari itu, peneliti juga mengharapkan agar tulisan dapat menjadi patokan serta menjadi referensi pembelajaran bagi kita. Oleh karena itu, peneliti merasa penting untuk mengangkat isu ini sebagai pembelajaran bagi kita agar lebih mengetahui lagi dan lebih waspada lagi terhadap apa pun bentuk kekerasan seksual yang terjadi di sekitar kita. 


\section{TINJAUAN PUSTAKA}

\section{Media Online}

Media online sering disebut sebagai media "generasi ketiga" setelah media cetak, surat kabar, tabloid, majalah, buku, media elektronik, dalam hal ini radio, televisi, film/video. Media adalah alat atau wadah, tetapi online adalah istilah yang diartikan sebagai informasi yang mudah diakses dari mana saja di Internet. Misalnya, media online seperti blog, website, atau media yang dipublikasikan dan disiarkan di dunia maya dapat dilihat dan dibaca di Internet. Secara fisik atau teknis, media online adalah media berbasis multimedia dan telekomunikasi (komputer dan internet) (Yunus, 2010).

Dalam perspektif studi media, media online menjadi objek kajian teori "new media" (media itu) adalah istilah yang mengacu pada permintaan akses terhadap konten (isi/informasi) kapanpun, dimanapun pada setiap perangkat digital serta umpan balik kepada pengguna yang interaktif, partisipasi kreatif, dan pembentukan komunitas sekitar konten media, juga aspek generasi "real time" (Wendratama, 2017).

Di sisi lain, menurut uraian media online disebut juga dengan media siber (cyber media), media internet (internet media) dan media baru (new media) dapat diartikan sebagai media yang disajikan secara online pada website. Pedoman Pemberitaan Media Siber (PPMS) yang diterbitkan Dewan Pers, mendefinisikan media siber sebagai berikut "segala bentuk media yang menggunakan wahana internet dan melaksanakan kegiatan jurnalistik, serta memenuhi persyaratan Undang-Undang Pers dan Standar Perusahaan Pers yang ditetapkan Dewan Pers".

\section{Pemberitaan Kekerasan Seksual Terhadap Anak}

Kekerasan dapat diartikan sebagai suatu perbuatan berdasarkan paksaan pihak lain tanpa persetujuan (Haryatmoko, 2007). Kekerasan juga mencakup sikap dominan terhadap orang dari segala bentuk, fisik, bahasa, spiritual, moral, dan psikologis. Oleh karena itu, pelecehan seksual memaksa anak untuk melakukan aktivitas seksual, atau memaksa perilaku seksual yang tidak pantas, termasuk aktivitas seksual atau interaksi seksual non fisik dengan anak. 
Media memasukkan isu kekerasan ke dalam pesannya sesuai dengan prinsip dasar penawaran dan permintaan. Sebuah pesan dalam bentuk dokumen atau gambar memiliki komponen penyedia, pemohon, dan pemangku kepentingan, dan ketiganya dikategorikan ke dalam produk yang bersifat sepihak dan saling menguntungkan. Fakta inilah yang menjadikan kekerasan atau kriminalitas sebagai aspek yang menarik dan berpotensi besar untuk disalahgunakan dan diperdalam untuk keuntungan finansial.

Jelas bahwa media massa memiliki banyak efek negatif, tanpa mengabaikan fungsi dan manfaat media massa dalam kehidupan sosial. Media massa dituding membawa dampak negatif bagi masyarakat. Seperti yang ditunjukkan Donald K. Roberts (1977), kami percaya bahwa efeknya hanyalah "perubahan perilaku manusia setelah terkena berita media massa". Karena pesan media massa, efeknya harus terkait dengan pesan media massa (Rakhmat, 2005).

Kekerasan di media berbahaya karena dapat mengubah transmisi kekerasan media menjadi kekerasan nyata dalam kehidupan sehari-hari. Media yang memuat berita tentang kekerasan yang berlebihan akan sangat merugikan anak dan remaja di kemudian hari. Paparan informasi tentang kekerasan mempengaruhi sikap dan perilaku anak terhadap kekerasan. Informasi tentang kekerasan juga dapat menimbulkan keresahan masyarakat sehingga menimbulkan sikap masyarakat yang menindas.

Berita mengenai kekerasan seksual hampir tiap hari menghiasi wajah berita di media massa, entah media cetak, elektronik maupun media online. Berita kekerasan yang masuk dalam kategori kriminalitas merupakan sasaran empuk bagi media untuk menyajikannya terhadap khalayak. Berita khususnya tentang kekerasan seksual terhadap anak. Media sangat beragam dalam bentuk kekerasan dan representasi subjek kekerasan. Kasus-kasus kekerasan biasanya dimuat di media yang dialami oleh orang-orang dari segala usia, dari anak-anak hingga orang dewasa. Anak-anak yang mudah tertipu dan tertarik, dan perempuan yang dianggap lemah sehingga tidak dihormati atau dilecehkan. Perempuan adalah salah satu target kekerasan yang paling banyak disebutkan dalam liputan media dan merupakan topik utama ketiga (3) liputan media. (www.aji.or.id). 
Isu kekerasan seksual terhadap anak akan "digoreng" oleh media untuk mendapatkan pembaca atau viewers. Bahkan tak jarang isu dilabeli dengan judul yang apa adanya dan terkesan terlalu panjang untuk sebuah judul berita. Media akhirnya turut memberitakan isu dan kasus yang sama dengan berbagai sudut pandang yang sekiranya dapat menarik perhatian khalayak pembaca. Bahkan beberapa judul berita ikut melanggar privasi korban dengan ikut menyebut identitas korban. Misal "Hamili Anak 15 Tahun, Pemuda 19 Tahun Ditangkap Dan Nyaris Dihakimi Warga" walaupun hanya menyebutkan umur korban, tetapi itu sudah masuk dalam privasi dan identitas korban. Alih-alih membantu, pengungkapan identitas ini malah membuat korban kejahatan seksual mengalami trauma karena masyarakat semakin mengetahui permasalahan yang dihadapi (www.aji.or.id).

Dengan mengungkap identitas korban dalam berita, selain kepercayaan diri korban, korban mengalami kehilangan privasi dan merasa tidak berharga. Pengungkapan identitas korban mengarah pada penghinaan dan keterasingan publik. Hal ini perlu dipahami dan dikoreksi oleh media, sehingga perlu melindungi privasi korban dan tulisan kriminal untuk mengurangi trauma yang dialami korban.

\section{Teori Agenda Setting}

Media massa selalu memberi tahu kita apa yang harus dilakukan. Media menyediakan agenda melalui produk cetak, elektronik dan online, dan masyarakat umum selalu mengikuti. Media memiliki kemampuan untuk memilah dan menyeleksi ide dan gagasan untuk suatu peristiwa tertentu untuk mendapatkan perhatian. Fenomena ini sesuai dengan teori agenda setting.

Teori agenda setting dikembangkan oleh profesor jurnalisme, Maxwell McCorm dan Donald Shaw. Mereka mengklaim bahwa media massa memiliki kemampuan untuk memindahkan wacana agenda berita ke agenda masyarakat umum. Kedua ahli percaya bahwa teori mempelajari media ini memiliki dua sisi. Dengan kata lain, kekuatan media dan kebebasan memilih pemirsa.

Teori ini juga berpendapat bahwa media memberitahu kita apa yang penting dan apa yang tidak. Bahkan media mengatur apa yang kita lihat dan siapa yang 
harus kita dukung. Menurut Menhaim konseptualisasi agenda berpotensi untuk lebih memahami proses agenda setting: agenda media, agenda khalayak, dan agenda kebijakan (Effendy, 2000). Masing-masing agenda tersebut mencakup aspek-aspek berikut:

Agenda media, Terdiri dari 3 sisi, yaitu: Visibility (visibilitas), yaitu jumlah dan tingkat menonjolnya berita. Audience salience (tingkat menonjol bagi khalayak), adalah relevansi isi berita dengan kebutuhan khalayak dan Valence (valensi), yakni menyenangkan atau tidak menyenangkan cara pemberitaan bagi suatu peristiwa.

Agenda Khalayak, Terdiri dari 3 sisi, yaitu : Familiarity (keakraban) adalah derajat kesadaran khalayak akan topik tertentu, Personal salience (penonjolan pribadi) merupakan relevansi kepentingan individu dengan ciri pribadi. Dan Favorability (kesenangan) adalah pertimbangan senang atau tidak senang akan topik berita.

Agenda kebijakan Terdiri dari 3 sisi, yaitu: Support (dukungan) merupakan kegiatan menyenangkan bagi posisi suatu berita tertentu, Likelihood of action (kemungkinan kegiatan) merupakan kemungkinan pemerintah melaksanakan apa yang diibaratkan dan Freedom of action (kebebasan bertindak) merupakan nilai kegiatan yang mungkin dilakukan pemerintah.

\section{Analisis Framing Robert N Entman}

Analisis framing merupakan analisis yang digunakan untuk melihat bagaimana media membangun realitas. Analisis framing juga digunakan untuk melihat seberapa baik suatu peristiwa dipahami dan dibingkai oleh media. Analisis framing mengasumsikan bahwa setiap individu (pelaku media) memiliki kecenderungan terhadap realitas yang ada dan pengalamannya sendiri, sehingga ia menekankan, mengurangi, atau menghapus fakta yang ada untuk menghilangkannya. Saya tertarik untuk memasukkannya ke dalam teks, gambar, atau menuangkan grafik (Suseno, 2013).

Robert Entmann adalah pelopor dalam analisis media dan ahli. Konsep framing dituangkan dalam artikel Journal Political Communication dan buku-buku lain yang mempraktekkan konsep tersebut dalam studi kasus liputan media. 
Menurut Entman, konsep ini digunakan untuk menjelaskan proses seleksi dan menonjolkan aspek realitas tertentu melalui media. Framing juga dapat dianggap sebagai menempatkan informasi dalam konteks yang unik sehingga topik tertentu dapat dieksplorasi lebih dalam dari yang lain.

Robert N. Entman melihat framing dalam dua aspek utama. Pemilihan topik dan penekanan atau penekanan pada aspek tertentu dari realitas/topik. Prominence adalah proses di mana informasi lebih bermakna, menarik, atau mudah diingat oleh audiens. Pada kenyataannya, pembingkaian dilakukan oleh media dengan memilih topik tertentu dan mengabaikan topik lainnya. Dan sorot aspek topik melalui banyak strategi wacana: penempatan yang mencolok (judul depan atau belakang), pengulangan atau penggunaan grafik untuk mendukung dan meningkatkan kognisi, ketika menggambarkan peristiwa yang dilaporkan.Penggunaan label khusus, asosiasi dengan simbol budaya, penyederhanaan, generalisasi, dll . (Mustika, 2017).

Tabel 2. Dimensi Framing Robert N Entman (Eriyanto, 2011)

\begin{tabular}{|l|l|}
\hline Seleksi Isu & $\begin{array}{l}\text { Aspek ini berhubungan dengan pemilihan fakta. Dari } \\
\text { realitas yang kompleks dan beragam itu, aspek mana } \\
\text { yang diseleksi untuk ditampilkan? Dari proses ini selalu } \\
\text { terkandung di dalamnya ada bagian berita yang } \\
\text { dimasukkan, tetapi ada juga berita yang dikeluarkan. } \\
\text { Tidak semua aspek atau bagian dari isu ditampilkan, } \\
\text { wartawan memilih aspek tertentu dari suatu isu }\end{array}$ \\
\hline Penonjolan Aspek & $\begin{array}{l}\text { Aspek ini berhubungan dengan penulisan fakta. Ketika } \\
\text { aspek tertentu dari isu tertentu dari suatu peristiwa/isu } \\
\text { tersebut telah dipilih, bagaimana aspek tersebut ditulis? } \\
\text { Hal ini sangat berkaitan dengan pemakaian kata, kalimat } \\
\text { gambar, dan citra tertentu untuk ditampilkan kepada } \\
\text { khalayak. }\end{array}$ \\
\hline
\end{tabular}

Sumber: Data sekunder peneliti, Januari 2021

Aspek pemilihan isu dilakukan oleh pihak redaksi dimana ada pemilihan isu yang nantinya disebarkan lewat pemberitaannya atau tulisan yang dimuat dalam media massanya. Tidak semua dapat ditampilkan oleh suatu media, oleh karenanya, isu yang sudah diterima oleh masyarakat adalah hasil dari penyeleksian dari wartawan dan redaksi media tersebut. Entman berpendapat bahwa framing 
bahkan bisa menjadi sebuah pandangan sendiri, ini disebabkan proses dari praktik jurnalistik yang demikian.

Ada pemilihan dan penonjolan isu dalam konsep entman terdapat empat elemen di dalam framing. Elemen-elemen tersebut adalah Problem Identification (Pendefinisian Masalah), Causal Interpretation (Mencari Penyebab Masalah) Make Moral Judgment (Membuat Keputusan Moral) dan Treatment Recommendation (Solusi Atas Masalah). Konsep Entman intinya merujuk pada pemberitaan definisi, penjelasan, evaluasi, dan rekomendasi dalam suatu wacana untuk menekan kerangka berpikir tertentu terhadap sebuah peristiwa yang diberitakan oleh media.

Penentuan empat elemen Entaman dapat memberikan hasil analisis isi media dan menunjukkan bingkai suatu media. Pertama, Define problem, adalah elemen yang pertama kali dapat kita lihat mengenai framing. Elemen ini merupakan master frame/bingkai yang paling utama. Menekankan bagaimana peristiwa dipahami wartawan.

Kedua ialah Diagnose cause, merupakan elemen framing untuk membingkai siapa yang dianggap sebagai aktor dari suatu peristiwa. Penyebab di sini bisa berarti apa (what), tetapi bisa juga berarti siapa (who). Bagaimana peristiwa dipahami, tentu saja menentukan apa dan siapa yang dianggap sebagai sumber masalah.

Berikutnya adalah Make moral judgement, adalah elemen framing yang dipakai untuk membenarkan/memberi argumentasi pada pendefinisian masalah yang sudah dibuat. Ketika masalah sudah didefinisikan, penyebab masalah sudah ditentukan, dibutuhkan sebuah argumentasi yang kuat untuk mendukung gagasan tersebut.

Terakhir, Treatment recommendation, elemen ini dipakai untuk menilai apa yang dikehendaki oleh wartawan untuk menyelesaikan suatu masalah, penyelesaian ini tergantung bagaimana peristiwa tersebut dipahami, siapa yang menjadi aktor penyebab, dan bagaimana argumen yang diajukan (Eriyanto. 2011). 


\section{METODE PENELITIAN}

Jenis penelitian ini adalah penelitian kualitatif deskriptif. Penelitian deskriptif merupakan pencarian fakta dengan interpretasi yang tepat. Penelitian ini mempelajari masalah-masalah dalam masyarakat serta situasi-situasi tertentu, termasuk hubungan, kegiatan-kegiatan, sikap-sikap, pandangan-pandangan, serta protes yang sedang berlangsung dan pengaruh dalam suatu fenomena (Prastowo, 2011:201). Model yang akan digunakan dalam penelitian ini adalah satu model yang diperkenalkan oleh Robert N Entman adalah salah seorang ahli yang meletakkan dasar-dasar bagi analisis framing untuk studi isi media.

Penelitian ini menggunakan pendekatan analisis teks. Analisis teks merupakan analisis yang digunakan untuk melihat bagaimana media memahami dan membentuk peristiwa dengan menggunakan model framing Robert N. Entman. Framing menekankan pada komunikasi teks yang ditampilkan dan bagaimana penulis teks menyoroti dan menganggapnya penting. Informasi yang mengesankan lebih mungkin diterima oleh masyarakat umum (Eriyanto, 2011). Oleh karena itu, analisis dengan Metode Framing Robert N Entman dinilai paling cocok untuk analisis berita kekerasan seksual terhadap anak di media online Kompas.com dan Detik.com.

Data Primer disini ialah berupa teks berita seputar isu kekerasan seksual terhadap anak pada media online Kompas.com dan Detik.com terbit edisi Juli 2020 yang peneliti telah kumpulkan dalam bentuk fisik. Sebelumnya, peneliti telah melakukan riset kecil untuk melihat jumlah berita yang masuk dalam kategori kekerasan seksual terhadap anak pada media Kompas.com dan Detik.com Peneliti juga menggunakan kata kunci dalam pencarian berita yang berkaitan seperti : Cabuli anak dan Hamili anak. Dari hasil pencarian ini peneliti menemukan 42 berita dari Kompas.com dan 49 berita dari Detik.com sehingga total keduanya sebanyak 91 berita.

Pemilihan berita yang dilakukan peneliti adalah menggunakan metode Purposive Sampling, yaitu pemilihan berita dengan sengaja serta cocok dengan kualifikasi sampel yang diinginkan. Syarat yang diperhatikan dalam memilih berita yang akan dianalisis ialah melihat kemiripan isi berita, baik dari judul maupun 
penggunaan katanya dalam menyusun berita dengan isu kekerasan seksual terhadap anak. Karena berita yang akan dianalisis bukan hanya pada satu kasus kekerasan seksual terhadap anak saja, melainkan semua kasus yang masuk dalam kategori kekerasan seksual terhadap anak. Maka, peneliti mengambil satu berita pada satu kasus kekerasan seksual saja. Sehingga peneliti mengumpulkan 6 berita dari Kompas.com dan 6 berita dari Detik.com, maka total 12 berita yang akan diteliti.

Data sekunder biasanya diperoleh dari buku, surat kabar, artikel, tulisan, dan lain-lain yang berhubungan dengan pokok bahasan penelitian. Data sekunder juga didukung dari berbagai sumber untuk melengkapi data yang diteliti. Data sekunder diperoleh dalam format yang telah disiapkan sebelumnya melalui publikasi dan informasi dari berbagai organisasi dan perusahaan, serta berbagai jurnal dan penelitian.

Pengumpulan data adalah prosedur yang sistematik dan standar untuk memperoleh data yang diperlukan. Data yang dikumpulkan harus cukup valid untuk digunakan. Validitas dari data dapat ditingkatkan jika alat pengukur serta kualitas dari pengambilan datanya sendiri cukup valid (Nazir, 1999). 1) Dokumentasi merupakan catatan peristiwa yang sudah lalu, dokumen bisa berbentuk tulisan atau gambar. Dokumentasi yang akan dilakukan peneliti ialah dengan mengunduh pemberitaan yang berkaitan dengan isu kekerasan seksual terhadap anak, berita tersebut dicatat dan dicetak link berita agar dapat dilihat dalam bentuk fisik. Pemilihan berita tersebut merupakan edisi terbit pada periode Juli 2020. 2) Observasi. Istilah observasi berasal dari bahasa latin yang berarti "melihat" dan "memperhatikan". Istilah observasi mengacu pada kegiatan memperhatikan, memperhatikan apa yang terjadi, dan mempertimbangkan hubungan antar aspek fenomena. Mengamati masalah adalah memantau. Teks berita dari kedua media online terkait kasus kekerasan seksual terhadap anak. 3) Penelitian kepustakaan ialah metode pengumpulan data dengan mengkaji serta mempelajari tulisan ilmiah yang berkaitan terhadap objek yang diteliti.

Instrumen penelitian merupakan alat bantu yang digunakan oleh peneliti dalam melakukan penelitiannya agar menjadi sistematis dan lebih mudah dalam penyusunannya. Pemilihan instrumen harus dievaluasikan sebaik mungkin agar 
informasi yang diinginkan untuk memperoleh data dapat dipercaya. Oleh karena itu, peneliti menggunakan alat berupa smartphone untuk mengakses berita yang dimuat pada Kompas.com dan Detik.com, serta alat tulis berupa buku dan juga pulpen.

Analisis data adalah suatu kegiatan yang mengorganisasikan, mengurutkan, mengkategorikan, mengkodekan/tag, dan mengkategorikan hasil berdasarkan fokus atau masalah yang dapat dijawab (Gunawan, 2013). Peneliti menganalisis data dalam beberapa tahapan, antara lain mengumpulkan data primer dan sekunder yang berkaitan dengan subjek penelitian, menganalisis data yang diperoleh dengan model analisis framing Robert N. Entmann, dan melengkapi hasil analisis yang meningkat.

Berikut Skema Framing Robert N Entman

Tabel 3. Skema Framing Robert N Entman

\begin{tabular}{|c|c|}
\hline $\begin{array}{l}\text { Define Problems (Pendefinisian } \\
\text { masalah) }\end{array}$ & $\begin{array}{l}\text { Bagaimana suatu peristiwa/isu } \\
\text { dilihat? Sebagai apa? Atau sebagai } \\
\text { masalah apa? }\end{array}$ \\
\hline $\begin{array}{l}\text { Diagnose Cause (Memperkirakan } \\
\text { masalah atau sumber masalah) }\end{array}$ & $\begin{array}{l}\text { Peristiwa itu dilihat disebabkan } \\
\text { oleh apa? Apa yang dianggap } \\
\text { sebagai penyebab dari suatu } \\
\text { masalah? Siapa (aktor) yang } \\
\text { dianggap sebagai penyebab } \\
\text { masalah? }\end{array}$ \\
\hline $\begin{array}{l}\text { Make moral judgement (Membuat } \\
\text { keputusan moral) }\end{array}$ & $\begin{array}{l}\text { Nilai moral apa yang disajikan } \\
\text { untuk menjelaskan masalah? Nilai } \\
\text { moral apa yang dipakai untuk } \\
\text { melegitimasi atau } \\
\text { mendelegitimasi suatu tindakan? }\end{array}$ \\
\hline $\begin{array}{l}\text { Treatment Recommendation } \\
\text { (Menekankan penyelesaian) }\end{array}$ & $\begin{array}{l}\text { Penyelesaian apa yang ditawarkan } \\
\text { untuk mengatasi masalah/isu? } \\
\text { Jalan apa yang ditawarkan dan } \\
\text { harus ditempuh untuk } \\
\text { mengatasi masalah? }\end{array}$ \\
\hline
\end{tabular}

Sumber : Data Sekunder Peneliti, Januari 2021

Define problem, adalah Elemen pertama yang bisa dilihat dari perspektif framing. Elemen ini adalah bingkai utama yang paling penting serta merupakan tekankan bagaimana wartawan memahami peristiwa tersebut.

Diagnose cause, merupakan elemen framing untuk membingkai siapa yang dianggap sebagai aktor dari suatu peristiwa. Penyebab di sini bisa berarti apa 
(what), tetapi bisa juga berarti siapa (who). Bagaimana peristiwa dipahami, tentu saja menentukan apa dan siapa yang dianggap sebagai sumber masalah.

Make moral judgement, digunakan untuk membenarkan/ memberi argumentasi pada pendefinisian masalah yang sudah dibuat. Ketika masalah sudah didefinisikan, penyebab masalah sudah ditentukan, dibutuhkan sebuah argumentasi yang kuat untuk mendukung gagasan tersebut.

Treatment recommendation, elemen ini berfungsi untuk menilai apa yang dikehendaki oleh wartawan untuk menyelesaikan suatu masalah, penyelesaian ini tergantung bagaimana peristiwa tersebut dipahami, siapa yang menjadi aktor penyebab, dan bagaimana argumen yang diajukan (Eriyanto, 2011).

Setelah ditemukan maka langkah kedua yaitu menjelaskan empat langkah penting dari analisis framing Robert N Entman, adalah berikut:

Tabel 4. Langkah Akhir Analisis Framing Robert N Entman

\begin{tabular}{|l|l|}
\hline $\begin{array}{l}\text { Problem } \\
\text { Identification }\end{array}$ & $\begin{array}{l}\text { Peristiwa dilihat sebagai sesuatu yang mana } \\
\text { positif dan yang mana negatif. }\end{array}$ \\
\hline $\begin{array}{l}\text { Causal } \\
\text { Interpretation }\end{array}$ & $\begin{array}{l}\text { Siapa atau apa yang dianggap penyebab } \\
\text { masalah. }\end{array}$ \\
\hline Moral Evaluation & Penilaian atas penyebab masalah. \\
\hline $\begin{array}{l}\text { Treatment } \\
\text { Recommendation }\end{array}$ & $\begin{array}{l}\text { Menawarkan suatu cara penanganan atau } \\
\text { solusi dari masalah dan kadang pula } \\
\text { memprediksikan hasilnya. }\end{array}$ \\
\hline
\end{tabular}

Sumber : Data Sekunder Peneliti, Januari 2021

Gambaran suatu permasalahan atau Problem Identification adalah tiang utama dari rangkaian proses membingkai tulisan di media atau suatu berita. Pada proses ini, peneliti harus menarik pokok dari suatu masalah yang sedang diangkat. Masalah ini merupakan hasil interpretasi dari redaksi dalam menyikapi peristiwa.

Berikutnya adalah diagnosa penyebab masalah. Proses ini dilihat ketika peristiwa yang dipahami media ditulis sedemikian rupa serta menonjolkan isu yang dianggap menjadi penyebab suatu masalah. Dalam hal ini, penyebab bukan hanya sebagai siapa, tetapi juga apa.

Tahap ketiga adalah Moral Evaluation. Pada tahap ini, masalah yang diidentifikasi dan penyebab yang diketahui disorot oleh ide-ide lain. Ide ini mendukung isu besar yang diangkat oleh media. Ide dapat berbentuk argumentasi 
dan merupakan jawaban dari seseorang yang mengetahui masalah secara andal dan diketahui secara umum.

Tahap terakhir adalah solusi yang diberikan media terhadap masalah yang diangkat. Pada fase ini sikap media digunakan sebagai masukan dan solusi dari permasalahan. Tentu saja, solusi ini tergantung pada masalah yang diangkat, penyebab masalah, dan perluasan masalah dengan ide-ide lain.

\section{HASIL DAN DISKUSI}

Pemilihan berita yang dilakukan peneliti adalah menggunakan metode Purposive Sampling, dimana pengambilan berita dengan sengaja serta sesuai dengan persyaratan sampel yang dibutuhkan. Syarat yang diperhatikan dalam memilih berita yang akan dianalisis ialah melihat kemiripan isi berita, baik dari judul maupun penggunaan katanya dalam menyusun berita dengan isu kekerasan seksual terhadap anak. Karena berita yang akan dianalisis bukan hanya pada satu kasus kekerasan seksual terhadap anak saja, melainkan semua kasus yang masuk dalam kategori kekerasan seksual terhadap anak. Maka, peneliti mengambil satu berita pada satu kasus kekerasan seksual saja. Sehingga peneliti mengumpulkan 6 berita dari Kompas.com dan 6 berita dari Detik.com, maka total 12 berita yang akan diteliti.

Tabel 5. Berita Kekerasan Seksual Terhadap Anak Pada Media Online Kompas.com Periode Terbit Juli 2020

\begin{tabular}{|l|l|l|l|}
\hline No & \multicolumn{1}{|c|}{ Tanggal Terbit } & \multicolumn{1}{|c|}{ Judul } & \multicolumn{1}{|c|}{ Penulis / Editor } \\
\hline 1 & $\begin{array}{l}\text { Sabtu (4 Juli 2020) } \\
\text { Pukul 14:23 WIB }\end{array}$ & $\begin{array}{l}\text { Petugas Sekuriti Diduga Cabuli 4 } \\
\text { Anak di Tangerang, KPAI : } \\
\text { Edukasi Anak Soal Cari } \\
\text { Pertolongan }\end{array}$ & $\begin{array}{l}\text { Muhammad } \\
\text { Bustomi / Nursita } \\
\text { Sari }\end{array}$ \\
\hline 2 & $\begin{array}{l}\text { Kamis (9 Juli 2020) } \\
\text { Pukul 18:14 WIB }\end{array}$ & $\begin{array}{l}\text { Guru SLB Cabuli Siswi } \\
\text { Penyandang Tuna Grahita } \\
\text { Hingga Hamil 7 Bulan }\end{array}$ & $\begin{array}{l}\text { Puthut Putranto Nugroho / } \\
\text { Khairina }\end{array}$ \\
\hline 3 & $\begin{array}{l}\text { Sabtu (11 Juli 2020) } \\
\text { Pukul 10:20 WIB }\end{array}$ & $\begin{array}{l}\text { Cabuli Anak Tiri Selama 2 Tahun, } \\
\text { Ayah di Pinrang Nikahkan } \\
\text { Korban Dengan Penyandang } \\
\text { Disabilitas, Ini Motifnya }\end{array}$ & $\begin{array}{l}\text { Candra Setia Budi } \\
\text { /Udin Syamsuddin }\end{array}$ \\
\hline
\end{tabular}




\begin{tabular}{|l|l|l|l|}
\hline 4 & $\begin{array}{l}\text { Rabu (15 Juli 2020) } \\
\text { Pukul 08:00 WIB }\end{array}$ & $\begin{array}{l}\text { Uang Belanja Tertinggal di } \\
\text { Rumah Ibu Dapati Suami } \\
\text { Perkosa Putrinya : Kok Tega } \\
\text { Hancurkan Anak Sendiri }\end{array}$ & $\begin{array}{l}\text { Idon Tanjung I } \\
\text { Abba Gabrillin }\end{array}$ \\
\hline 5 & $\begin{array}{l}\text { Kamis (16 Juli 2020) } \\
\text { Pukul 12:56 WIB }\end{array}$ & $\begin{array}{l}\text { Kakek Sakit Struk Ini Ternyata } \\
\text { Cabuli Cucu Sendiri Selama 4 } \\
\text { Tahun }\end{array}$ & $\begin{array}{l}\text { Amriza Nursatria } \\
\text { / Aprillia Ika }\end{array}$ \\
\hline 6 & $\begin{array}{l}\text { Rabu (29 Juli 2020) } \\
\text { Pukul 10:47 WIB }\end{array}$ & $\begin{array}{l}\text { Buruh Harian Selama 4 Tahun } \\
\text { Cabuli Anak Tiap-Tiap Malam, } \\
\text { Semat Kepergok Istri }\end{array}$ & $\begin{array}{l}\text { Heru Dahnur } \\
\text { / Aprillia Ika }\end{array}$ \\
\hline
\end{tabular}

Data Primer Peneliti : Maret 2021

Kompas.com jika ditinjau dari konten beritanya memuat banyak komentar dari pihak kepolisian bahkan dari enam berita yang dianalisis peneliti selalu memuat kutipan wawancara dari pihak berwajib. Kompas.com tidak mengutip satupun keterangan pelaku. Hal ini jelas bahwa secara tidak langsung Kompas.com ingin melindungi korban dengan tidak memberikan ruang lebih untuk pelaku membela diri pada publik melalui media. Selain mengutip wawancara pihak berwajib, Kompas.com dalam konten beritanya dengan jelas menulis pasal yang dikenakan kepada pelaku dan masa tahanan yang akan dijalani.

Judul berita pada Kompas.com terkesan netral dan tidak memberikan diksi untuk menambahkan kesan dramatis, judul terkesan apa adanya dan netral ini memuat kutipan pernyataan narasumber seperti pada berita pertama dan berita keempat pada Kompas.com.

Tabel 6. Berita Kekerasan Seksual Terhadap Anak Pada Media Online Detik.com Periode Terbit Juli 2020

No Tanggal Terbit Judul Penulis / Editor

1 Rabu (1 Juli 2020) Predator Seks Sukabumi Ngaku Ke Syahdan Alamsyah pukul 20:38 WIB Polisi Telah Cabuli 30 Orang Anak

2 Minggu (5 Juli 2020) Bejat Sekuriti Cabuli 4 Anak Gegara Jehan Nurhakim Pukul 07:02 WIB Cerai Dengan Istri

3 Kamis (9 Juli 2020) Saat Digrebek WNA Cabuli 305 Anak Yogi Ernes Pukul 21:58 WIB Sedang Setengah Bugil Dengan 2 ABG

4 Sabtu (11 Juli 2020) Menyedihkan, Korban Pencabulan Amir Baihaqi Pukul 16:11 WIB Penjaga Makam Ada Yang Ditinggal Orang Tuanya

5 Jumat (17 Juli 2020) Kasus Penculikan 8 Anak di Depok, Jehan Nurhakim Pukul 20:28 Pelaku Juga Cabuli Korban

6 Selasa (21 Juli 2020) Pukul 20:08 Alasan Kakek 72 Tahun Cabuli Bocah Ainur Rofiq Hanya Untuk Menghibur Diri 


\section{Data Primer Peneliti : Maret 2021}

Jika ditinjau dari judul berita pada Detik.com cenderung menggiring opini publik dengan memilih diksi tertentu seperti "Bejat", "Predator Seks", "Menyedihkan" untuk menambah kesan dramatis pada berita. Hal ini terdapat pada 3 judul berita di antara 6 berita lainnya. Hal ini menunjukan bahwa berita yang terdapat pada Detik.com banyak menggunakan kata atau kalimat opini dari kacamata wartawan atau media itu sendiri.

Selanjutnya jika dilihat dari sisi konten beritanya Detik.com pada beberapa beritanya memuat komentar atau kutipan wawancara pelaku, bahkan terdapat 1 berita yang hanya berisi 1 kutipan wawancara yang hanya berasal dari pelaku. Hal ini memberikan gambaran kepada pembaca bahwa Detik.com cenderung memberikan ruang kepada pelaku untuk berbicara kepada publik melalui media. Bahkan tak jarang kutipan tersebut memuat pembelaan terhadap pelaku atau menceritakan kasu ini berdasarkan sudut pandang pelaku.

\section{Komparasi Framing Pemberitaan Kasus Kekerasan Seksual Terhadap Anak pada Media Online Kompas.com Dan Detik.com}

Framing pada pemberitaan tidak lepas dari penulis berita yang dipengaruhi oleh pengalaman, dan ilmu pengetahuan masing-masing individu. Selain individu, kriteria yang dimiliki media juga memberikan pengaruh terhadap bagaimana media mengemas sebuah realitas menjadi berita. Framing juga dapat menggiring opini masyarakat terhadap suatu isu.

Menurut Entman, framing adalah alat untuk memilih beberapa aspek pemahaman kehidupan nyata dan menyoroti mereka dalam definisi masalah tertentu, baik dalam interpretasi, evaluasi moral, dan rekomendasi solusi. Masalah yang disajikan. (Suf, 2010). Media yang berbeda pasti mempunyai bingkai berbeda dalam melihat suatu isu atau peristiwa. Hal ini tentu didorong oleh visi misi, sejarah dan kebijakan redaksi masing-masing medianya. Berita pelecehan dan kekerasan seksual dimuat dalam berita kriminal yang berbeda dengan berita lain seperti bisnis dan politik. Sumber utama perbedaan terletak pada bahan baku, dan bahan baku berita kriminal adalah realitas sosial yang melanggar hukum yang berlaku. 
Kekerasan seksual sendiri seperti tidak mempunyai batasan, siapa pun bisa jadi korban dari pelaku yang bahkan bisa jadi orang yang paling dekat dengan kita. Kekerasan seksual sendiri merupakan bentuk aktivitas yang dilakukan pelaku kepada korban yang biasanya diikuti sebuah ancaman kekerasan. Mayoritas masyarakat Indonesia yang orientasi keluarga yang kuat, membuat penanganan terhadap korban biasanya dihalang oleh keluarga sendiri dengan alasan menjaga nama baik keluarga, atau untuk mempertahankan martabat keluarga. Sama halnya dengan bagaimana media membingkai setiap pemberitaan terkait isu ini.

Define Problems. Dalam hal ini Kompas.com dan Detik.com sama-sama mengangkat masalah terhadap isu yang sama yaitu kekerasan seksual terhadap anak. Namun Kompas.com dalam pemberitaannya berusaha melindungi korban dan berpihak pada korban. Hal ini diperkuat dengan narasumber yang dipilih Kompas.com adalah dari pihak kepolisian yang kutipannya banyak membahas ganjaran dan pasal terkait terhadap pelaku pencabulan dan kekerasan seksual terhadap anak temuan ini terdapat pada semua korpus berita peneliti. Lain halnya dengan Detik.com, di antara 6 berita terdapat 3 berita yang mengutip pernyataan yang menganggap biasa perbuatan pelaku yang secara tidak langsung akan dianggap suatu yang normal dengan alasan tertentu. 3 berita yang dimaksud adalah 1 berita yang memuat kutipan paman pelaku dan 2 berita dengan mengutip pernyataan pelaku langsung.

Seharusnya wartawan berpegang teguh pada prinsip kejurnalistikan dan dituntut lebih sensitif dalam memberitakan isu tertentu apalagi isu kekerasan seksual yang melibatkan anak. Beberapa prinsip dasar dalam meliput anak ini sudah dikeluarkan oleh berbagai lembaga. Salah satunya bersumber dari International Federation of Journalist (IFJ) seperti menghindari presentasi yang mengandung stereotip (stigmatisasi) dan sensasional dalam mempromosikan konten jurnalistik yang melibatkan anak (Agam, ddk, 2017).

Diagnose Cause. Pandangan peneliti menemukan bahwa kompas.com melihat kasus ini banyak dilakukan oleh keluarga terdekat korban bahkan yang masih berstatus sebagai keluarga dekat. Pada pemberitaan Kompas,com 4 dari 6 berita kasus kekerasan seksual ini disebabkan oleh keluarga korban. 1 berita dilakukan oleh kakek korban, dan 3 berita lainnya pelakunya adalah ayah korban 
sendiri. Berbeda jauh dengan apa yang dibingkai oleh Detik.com. Detik.com membingkai kasus kekerasan seksual terhadap anak sering dilakukan oleh orang yang bukan anggota keluarga korban. Peneliti dalam korpus tidak mendapat satupun berita yang pelakunya adalah kakek atau ayah korban, melainkan pelakunya adalah pemuda setempat, WNA, bahkan sekuriti setempat yang tidak satupun dari mereka mempunyai hubungan keluarga dengan korban.

Moral Evaluation. Kompas.com melihat kasus ini banyak terjadi karena korban yang merupakan anak-anak mendapatkan ancaman dari pelaku misal ancaman dibunuh, dipukul, bahkan ancaman akan disantet. Hal ini terdapat pada 3 di antara 6 berita yang diterbitkan Kompas.com.

Sedangkan Detik.com melihat penyebabnya berbeda. Detik.com berasumsi setidaknya ada dua hal yang ditekankan menjadi penyebab masalah ini. Pertama, korban diberikan iming-iming berupa uang, akan dijadikan model, bahkan imingiming ilmu kekebalan tubuh. Kedua, pelaku melakukan kekerasan seksual karena ingin memenuhi kebutuhan hasrat seksualnya. Penjelasan di atas terdapat pada 3 di antara 6 berita Detik.com.

Elemen terakhir yaitu Treatment Recommendation. Kompas.com dan detik.com sama-sama melihat kasus ini masuk dalam ranah hukum. Maka tidak heran narasumber yang dipilih kedua media ini didominasi oleh pihak berwajib dalam hal ini kepolisian atau Unit PPA. Kompas.com secara tegas menuliskan ganjaran yang didapatkan pelaku dengan mencantumkan jenis pasal yang dilanggar serta masa hukuman penjara yang akan dijalani oleh para pelaku. Misalnya "dijerat dengan pasal 81 ayat 3 UU RI tentang perlindungan anak Junto pasal 36 B dan penjara 15 tahun" atau "Pelaku dijerat dengan pasal 81 UU No 17 tahun 2016 dengan penjara 4 tahun". Hal ini dapat ditemukan pada 4 dari 6 berita Kompas.com.

Sedangkan solusi yang ditawarkan Detik.com hanya berakhir pada diamankan pelaku oleh pihak berwajib. Detik.com tidak mencantumkan jelas jenis pasal yang dilanggar serta masa hukuman yang akan dijalani oleh pelaku seperti halnya yang dilakukan oleh Kompas.com di atas. Misalnya "Pelaku diamankan oleh Unit PPA Polres Sukabumi" atau "Pelaku diamankan oleh Sat Reskrim Pelabuhan Tanjung Perak Surabaya". Hal ini dapat ditemukan pada 4 dari 6 berita Detik.com. 
Padahal jika membahas masalah anak berarti juga membahas masalah gender. Pemberitaan dari Kompas.com dan Detik.com bias gender dimana korban memberikan stigma negatif yang dianggap sebagai makhluk yang rentan untuk dijadikan objek kekerasan orang dewasa. Tidak mengherankan dalam teks semacam ini perempuan (korban) selalu menjadi objek penceritaan, selalu dipandang dan direpresentasikan secara buruk. Perempuan korban kekerasan justru tidak diberi ruang untuk menceritakan peristiwa yang dialaminya (Heriyantie, 2017).

Sifat media yang cepat dalam menyajikan berita memberikan kesempatan lebih besar untuk memperbaharui berita sebelumnya, hal ini dilakukan media demi memenuhi kebutuhan informasi pembacanya yang tentu harus berpegang teguh pada prinsip-prinsip dalam menulis berita dan menerbitkannya sehingga dapat memberikan manfaat lebih banyak kepada khalayak. Pada kasus ini, berita bukan hanya laporan peristiwa. Ada sesuatu yang disiarkan dalam sebuah berita. Kadangkadang makna yang tersirat jauh lebih penting daripada berita yang tersurat. Khalayak tidak hanya membaca berita yang tersurat, tapi juga yang tersirat.

Dalam teorinya Maxwell McComb dan Donald Shaw berpendapat bahwa khalayak bebas memilih berita yang ingin dibaca, tetapi di sisi lain media juga punya kekuatan untuk mengontrol berita yang disajikan. Pada akhirnya media akan selalu memandu dan mengarahkan perhatian masyarakat pada isu. Seperti halnya isu kekerasan seksual terhadap anak baik Kompas.com dan Detik.com akan menyajikan berita dengan sudut pandang masing-masing. Hal ini berkaitan dengan teori agenda setting dimana kedua media tersebut punya cara masing-masing dalam mengontrol bacaan masyarakat.

Media seharusnya menggunakan cara strategis untuk menyaring isu kekerasan terhadap perempuan dan anak, kemudian menyajikan realitas sosial kekerasan terhadap perempuan dan anak, lalu mengedukasi masyarakat bagaimana menyikapi isu tersebut secara sadar 


\section{KESIMPULAN}

Berdasarkan framing Robert $\mathrm{N}$ Entman terhadap berita isu kekerasan seksual terhadap anak maka dapat disimpulkan bahwa Kompas.com cenderung melindungi korban dengan tidak memberikan ruang lebih untuk pelaku membela diri pada publik melalui media serta memastikan pelaku mendapatkan ganjaran sesuai dengan UUD yang berlaku. Detik.com cenderung memberikan ruang kepada pelaku untuk melakukan pembelaan melalui kutipan wawancara dalam pemberitaan. Kompas.com dan Detik.com memberitakan isu yang sama dalam hal ini kekerasan seksual terhadap anak. Jika ditinjau dari isi beritanya keduanya memiliki bingkai berbeda dalam menggiring opini masyarakat. Kompas.com berasumsi bahwa pelaku kekerasan seksual banyak datang dari keluarga dekat korban. Kemudian Kompas.com melihat bahwa korban sering mendapat ancaman seperti dibunuh atau dipukul oleh pelaku. Kompas.com juga secara tegas menulis ganjaran yang akan didapat oleh pelaku. Sedangkan Detik.com melihat pelaku justru datang dari orang yang tidak punya hubungan keluarga. Detik.com juga berasumsi bahwa pelaku meperdayai korban dengan iming-iming uang untuk melancarkan aksinya. Solusi yang diberikan oleh Detik.com tidak menuliskan secara jelas ganjaran yang didapatkan oleh pelaku.

Adapun saran berdasarkan hasil peneitian ini adalah sebagai berikut: 1) sebaiknya pemberitaan isu kekerasan seksual dibarengi dengan berita mengenai penanganan oleh Dokter atau Psikolog mengingat kejadian ini menimbulkan trauma mendalam bagi korban terlebih anak-anak. Sehingga media tidak menambah trauma baru bagi korban. 2) Peliputan dengan menerapkan Jurnalisme Sensitif Gender seharusnya dapat diterapkan pada media sehingga kasus kriminal yang meliputi kekerasan, atau pemerkosaan yang menjadikan anak-anak atau perempuan sebagai korbannya tidak menambah citra buruk pada korban dan tidak menimbulkan trauma berkelanjutan. 3) Penelitian ini diharapkan dapat dilanjutkan kedepannya dengan mengangkat metode penelitian berbeda. Misalnya, dapat dikombinasikan dengan analisis. 


\section{DAFTAR PUSTAKA}

Agam Sofyan, Qodriansyah dkk. (2017). Panduan Jurnalis dalam Meliput Isu Anak, Cet. I: AJI Makassar

Alexa. Top Sites. diakses pada tanggal 13 Desember 2020, 13.22 WITA https://www.alexa.com/topsites/countries/

Aliansi Jurnalis Independen (AJI). 11 Desember 2012. Masih Ada Kekerasan Pada Perempuan di Media. diakses pada 27 Maret 2021, 16:12 WITA. https://aji.or.id/read/berita/163/masih-adakekerasan-pada-perempuan-di$\underline{\text { media }}$

Aliansi Jurnalis Independen (AJI). 11 Junuari 2021. Etika Peliputan Privasi dalam Peliputan Kejahatan. diakses pada 27 Maret 2021, 18:12 WITA https://aji.or.id/read/alert-id/48/etika-perlindungan-privasi-dalampeliputan-kejahat/

Effendy, O. U. O. U. (2000). Ilmu teori dan filsafat komunikasi. Bandung: Citra Aditya Bakti

Eriyanto. Analisis Framing. Konstruksi, Ideologi, dan Politik Media. Yogyakarta: LkiS Yogyakarta, 2011.

Gunawan, I. (2013). Metode penelitian kualitatif. Jakarta: Bumi Aksara, 143.

Haryatmoko. Etika Komunikasi, Yogyakarta: Kanisius, 2007.

Hasanah, H. (2013). Kekerasan Terhadap Perempuan Dan Anak Dalam Rumah Tangga Perspektif Pemberitaan Media. Sawwa: Jurnal Studi Gender, 9(1), 159178.

Heriyantie, Y. N. (2007). Perempuan Korban Kekerasan Dalam Konstruksi Teks Berita Kekerasan Pada Surat Kabar Pos Kota, Indo Pos, Warta Kota dan Berita kota. KOMUNIKOLOGI: Jurnal Ilmiah IImu Komunikasi, 4(2).

Hurairah, Abu. (2012). Kekerasan Terhadap Anak. Bandung: Nuasa Press

Indira Rezkisari. 19 Juni 2020. 1 Miliar Anak di Dunia Alami Kekerasan tiap Tahunnya .Diakses pada 23 Juli 2020, 13:23 WITA https://www.republika.co.id/berita/qc5bdu328/1-miliar-anak-di-duniaalami-kekerasan-tiap-tahunnya

Khomsahrial, R. (2016). komunikasi massa. jakarta: Pt Grasindo. 
Matius Alfons. 24 Juli 2019. LPSK : Kasus Kekerasan Seksual pada anka Meningkat Tiap Tahun. Diakses pada tanggal 23 Desember 2020, 14 : 11 WITA)https://news.detik.com/berita/d-4637744/lpsk-kasus-kekerasanseksual-pada-anak-meningkat-tiap-tahun.

Mustika, Rieka . "Analisis Framing Pemberitaan Media Online Mengenai Kasus Pedofilia di Akun Facebook". Jurnal Penelitian Komunikasi, Vol. 20 No. 2 (2017)

Nazir. 1999. Metodologi Penelitian, cetakan keempat. Jakarta : Ghalia Indonesia

Paramastri, I., \& Priyanto, M. A. (2010). Early prevention toward sexual abuse on children. Jurnal Psikologi, 37(1), 1-12.

Prastowo, A. (2011). Memahami metode-metode penelitian. Yogyakarta: Ar-Ruzz Media.

Setiati, E. (2005). Ragam jurnalistik baru dalam pemberitaan. Yogyakarta: Penerbit Andi.

Suf, K. (2010). Pers dan Pencitraan Umat Islam Di Indonesia. Balai Litbang dan Diklat Kementerian Agama RI: Desember.

Suseno, Desy Dwiastuti. "Kasus Korupsi dalam Foto Berita Kompas: Analisis Semiotika Rolland Barthes Pada Foto Berita Kasus Dugaan Korupsi Pengadaan Alat Simulasi Berkendara Di Korps Lalu Lintas Polri”. Skripsi. Purwokerto, STAIN:2013.

Wendratama, Engelbertus. Jurnalisme Online: Panduan Membuat Konten yang Berkualitas dan Menarik. Yogyakarta: B first, 2017.

Yunus, Syarifudin. (2010). Jurnalistik Terapan. Jakarta: Ghalia Indonesia 